\title{
An approach to estimate carbon stocks change in forest carbon pools under the UNFCCC: the Italian case
}

\begin{abstract}
Federici $S^{*(1)}$, Vitullo $M^{(2)}$, Tulipano $S^{(1)}$, De Lauretis $R^{(2)}$, Seufert $G^{(1)}$
Under the UNFCCC, Annex I Parties must report annually a National GHG Inventories of anthropogenic emissions by sources and removals by sinks. LULUCF is one of the six sectors of the inventory: in this sector any emissions and removals of GHGs by land management should be reported, included the large GHGs fluxes generated by forest management and land-use changes into and from forest. In this context every Party has to produce a proper model in order to be able to fulfil GHGs Inventory request for forest sector. Taking Italy as a study case, the paper aims at presenting a new methodology for updating stock changes for years between national forest inventories, in order to reproduce annual stock changes in the five UNFCCC forest carbon pools, following the UNFCCC requirements in the context of carbon reporting.
\end{abstract}

Keywords: Carbon stock, GHG inventory, LULUCF, yield model, sink, C pools

\section{Introduction}

Under the United Nations Framework Convention on Climate Change (UNFCCC) each industrialised country listed in Annex I of the Convention must report annually a $\mathrm{Na}-$ tional Greenhouse Gas Inventory of its anthropogenic emissions by sources and removals by sinks of greenhouse gases (GHGs) not controlled by the Montreal Protocol.

One out of six sectors of the inventory concerns Land Use, Land-Use Change and Forestry categories (LULUCF). In this sector any emissions and removals of GHGs by managed land should be reported. Among land uses, forest land use is one of the most relevant, due to large carbon pools and associated large GHGs fluxes generated by forest management and land-use changes into and from forest.

Interrelations between forest and climate system have been a major focus of research since mid-1980s. Up to date, several models have been developed that analyze and simu-

(1)European Commission's Joint Research Centre, Climate Change Unit, via E. Fermi 1, Ispra (VA - Italy); ${ }^{(2)}$ APAT, Agenzia per la Protezione dell'Ambiente e per i Servizi Tecnici, via C. Pavese 313, Roma (Italy)

${ }^{*}$ Corresponding Author: Sandro Federici (sandro.federici@gmail.com).

Received: Jun 14, 2007 - Accepted: Jan 24, 2008

Citation: Federici S, Vitullo M, Tulipano S, De Lauretis R, Seufert G, 2008. An approach to estimate carbon stocks change in forest carbon pools under the UNFCCC: the Italian case. iForest 1: 86-95 [online: 2008-05-19] URL: http://www.sisef.it/iforest/ late carbon budgets and fluxes at level of forest stands. These tools range from very detailed models based on ecophysiological processes and driven by environmental parameters (e.g., Waring \& Running 1998) to very general empirical, descriptive models of carbon budgets within forest stands (e.g., Masera et al. 2003). None of these models have been widely used for operational application, and none of them has been adopted as standard for carbon reporting under UNFCCC. As the main reason for this we consider the age dependency of all these models in which all stand variables being driven by the age of the forest/plantation. In reality, however, growth is strictly related to species and to local environmental conditions. In this respect the most realistic estimates of carbon stock changes have to be derived by yield models, whose input data are directly connected with National Forest Inventories (NFI). UNFCCC requirements in the context of carbon reporting also require a series of features for forest sector which are only compatible with yield models. Under current UNFCCC reporting guidelines (IPCC 2000, IPCC 2003) estimates of carbon stock changes in the forest sector must still be based on national forest inventories and yield models. In this context every Country is encouraged to produce a proper national model in order to be able to annually fulfil GHG's Inventory request for the forest sector.

To be utilized for UNFCCC reporting the model shall respond to some characteristics: 1. it shall be based on: (i) official statistical data like the National Forest Inventory and national forest statistics; (ii) peer reviewed scientific dataset;
2. it shall produce annual carbon stock changes in each carbon pool;

3. it shall be accurate and, in the Kyoto Protocol perspective, conservative (i.e., neither overestimate increases nor underestimate decreases in carbon stocks in carbon pools).

A general complication for UNFCCC carbon reporting in the forestry sector is connected to the need of annual reporting since 1990, whereas NFI's are performed in cycles of 5-10 years in some countries with best case of NFI data availability. In Italy, for example, there is a NFI available for the year 1985 and a new NFI is still ongoing. Anyway, considering the timing of NFIs, there is the need of reporting carbon stock changes for any year between consecutive inventories with a reliable methodology, based on growth relationships and annually measured forest parameters, rather than a simple extrapolation between years.

Following the above rationale, we propose a new methodology, which is based on existing NFI data for 1985 and new forest area estimates from the ongoing NFI, in order to reproduce annual stock changes in the five UNFCCC forest carbon pools (IPCC 2003). Taking Italy as an example, the paper aims at presenting a methodology for updating stock changes for years between national forest inventories, which could eventually be used also for other countries with similar data availability (Tab. 1).

Tab. 1 - Forest areas from 1985 to 2006.

\begin{tabular}{cc}
\hline Year & $\begin{array}{c}\text { Forest area } \\
\text { (kha) }\end{array}$ \\
\hline 1985 & 8675 \\
1986 & 8793 \\
1987 & 8908 \\
1988 & 9028 \\
1989 & 9145 \\
1990 & 9263 \\
1991 & 9380 \\
1992 & 9498 \\
1993 & 9616 \\
1994 & 9733 \\
1995 & 9851 \\
1996 & 9968 \\
1997 & 10086 \\
1998 & 10203 \\
1999 & 10321 \\
2000 & 10438 \\
2001 & 10556 \\
2002 & 10674 \\
2003 & 10791 \\
2004 & 10909 \\
2005 & 11026 \\
2006 & 11144 \\
& \\
\hline
\end{tabular}


Tab. 2 - Biomass Expansion Factors, Wood Basic Densities for aboveground biomass estimate and Root/Shoot ratio.

\begin{tabular}{|c|c|c|c|c|}
\hline \multirow[b]{2}{*}{ Typology } & \multirow[b]{2}{*}{$\begin{array}{c}\text { Inventory } \\
\text { typology }\end{array}$} & BEF & \multirow{2}{*}{\begin{tabular}{|c} 
Wood Basic \\
Density
\end{tabular}} & \multirow{2}{*}{$\begin{array}{c}\text { R } \\
\begin{array}{c}\text { weight of below- } \\
\text { ground } \\
\text { biomass / weight } \\
\text { of growing stock }\end{array}\end{array}$} \\
\hline & & $\begin{array}{c}\text { volume of above- } \\
\text { ground biomass / } \\
\text { volume of growing } \\
\text { stock }\end{array}$ & & \\
\hline \multirow{11}{*}{ Stands } & norway spruce & 1.29 & 0.38 & 0.29 \\
\hline & silver fir & 1.34 & 0.38 & 0.28 \\
\hline & larches & 1.22 & 0.56 & 0.29 \\
\hline & mountain pines & 1.33 & 0.47 & 0.36 \\
\hline & mediterranean pines & 1.53 & 0.53 & 0.33 \\
\hline & other conifers & 1.37 & 0.43 & 0.29 \\
\hline & european beech & 1.36 & 0.61 & 0.20 \\
\hline & turkey oak & 1.45 & 0.69 & 0.24 \\
\hline & other oaks & 1.42 & 0.67 & 0.20 \\
\hline & other broadleaves & 1.47 & 0.53 & 0.24 \\
\hline & partial total & 1.35 & 0.51 & 0.28 \\
\hline \multirow{9}{*}{ Coppices } & european beech & 1.36 & 0.61 & 0.20 \\
\hline & sweet chestnut & 1.33 & 0.49 & 0.28 \\
\hline & hornbeams & 1.28 & 0.66 & 0.26 \\
\hline & other oaks & 1.39 & 0.65 & 0.20 \\
\hline & turkey oak & 1.23 & 0.69 & 0.24 \\
\hline & evergreen oaks & 1.45 & 0.72 & 1.00 \\
\hline & other broadleaves & 1.53 & 0.53 & 0.24 \\
\hline & conifers & 1.38 & 0.43 & 0.29 \\
\hline & partial total & 1.39 & 0.56 & 0.27 \\
\hline \multirow[t]{7}{*}{ Plantations } & eucalyptuses coppices & 1.33 & 0.54 & 0.43 \\
\hline & $\begin{array}{l}\text { other broadleaves cop- } \\
\text { pices }\end{array}$ & 1.45 & 0.53 & 0.24 \\
\hline & poplars stands & 1.24 & 0.29 & 0.21 \\
\hline & $\begin{array}{l}\text { other broadleaves } \\
\text { stands }\end{array}$ & 1.53 & 0.53 & 0.24 \\
\hline & conifers stands & 1.41 & 0.43 & 0.29 \\
\hline & others & 1.46 & 0.48 & 0.28 \\
\hline & partial total & 1.36 & 0.40 & 0.25 \\
\hline \multirow{4}{*}{ Protective } & rupicolous forest & 1.44 & 0.52 & 0.42 \\
\hline & riparian forest & 1.39 & 0.41 & 0.23 \\
\hline & shrublands & 1.49 & 0.63 & 0.62 \\
\hline & partial total & 1.46 & 0.56 & 0.50 \\
\hline Total & - & 1.38 & 0.53 & 0.30 \\
\hline
\end{tabular}

\section{The For-est (Forest Estimates) \\ Model}

In forest science, estimates of the current increment has always been related with age of forest stand (as in yield tables) in order to define the proper rotation period, which depends on age and productivity of the stand. Age could be the best parameter for productivity assessment of single trees, but it is not always appropriate for estimates at the stand level. This is particularly true for natural stands, where forest dynamics is driven by optimised use of natural resources, which includes tree mortality and natural regeneration in gaps. These processes result in a complex mosaic of different ages or cohortes; under these conditions the use of age dependant relationships for productivity estimations is not always appropriate.

The type of forest management outlined above is especially common in Mediterranean countries, where even-aged stand is not the rule. Correspondingly, Garcia (1993) writes: "The use of age on the right-handside (as independent variable) is conceptually unsatisfactory in that, at least in the sense of elapsed time $t$, it does not have a physical presence (other than as a number of growth rings), and therefore should not be given a causal meaning. Actually, when foresters say age they often think size."

Lähde et al. (1994) made an analysis on the relation between variables for various forest structures and compositfions, showing a higher correlation between current increment and growing stock compared to current increment and age.

There are various studies showing a relation among dimensional attributes of trees without considering the age (Moser \& Hall 1969, Zeide 1993, Thrower 2003, Garcia 1979, Garcia 1983, Rennolls 1995, Birch 1999, Damgaard 1998, Damgaard 1999, Damgaard et al. 2002, Khatouri \& Dennis 1990, Atta-Boateng \& Moser 2000, Wyszomirski et al. 1999, Duerr \& Gevorkiantz 1938, Kolström 1993, Moser 1972). For instance, Chrimes (2004) demonstrates that current increment is directly and significantly related to volume.

Thrower (2003) formulated an equation that calculates current increment as a function of growing stock and of Potential Site Index (PSI) considering this as a variant of the Langsaeter curve, which consists in a univocal relation between stand density and current increment (Langsaeter 1944).

For these reasons, and because of the large majority of Italian forest are not even-aged, we propose to use an approach based on growth curves not dependant on age but considering the growing stock as independent variable and the current increment as dependent one.

We further propose that all carbon stocks in carbon pools shall be estimated in function of the growing stock. This is an advantage compared to other approaches since the growing stock is closely related with other carbon budget components such as soil car-



Fig. 1 - Example of Richards function (first derivative) fitting Larix decidua. Comune di Cesana Torinese (TO) - Piano d'assestamento 1963-1972. Parameters: $\mathrm{a}=$ 446.1937; $\mathrm{k}=$ $0.0336 ; v=$ $0.4889 ; \mathrm{y}_{0}=$ $0.21719 ; \mathrm{R}^{2}=$ $0.9149003 ; \mathrm{ME}=$ 0.9157618 . 
Fig. 2 - Example of Richards function (first derivative) fitting -

Picea excelsa.

Comune di

Borno (BS).

(Parameters: $\mathrm{a}=$

978.6552; $\mathrm{k}=$

$0.0139 ; v=$

$-0.2757 ; \mathrm{y}_{0}=$

0.06267 ;

$\mathrm{R}^{2}=0.54880459$;

$\mathrm{ME}=-2.794501)$.

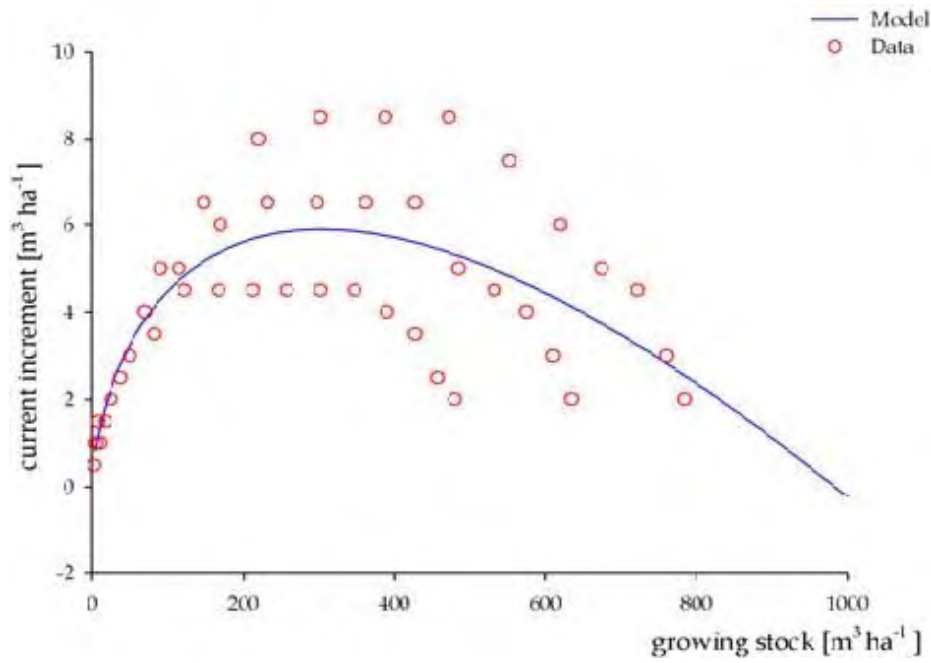

bon, litter, deadwood etc. and it is a unique driver, simply assessable, widely and iteratively sampled on national territory (by NFIs). Moreover, growing stock data could be verified using independent dataset as regional forest inventories and/or local forest management plan.

In order to calculate current increment as a function of growing stock the Richards function (Richards 1959) has been selected. Based on a biologically realistic model, the Richards function is a bounded and a monotonic one, with 4 parameters; it is very appropriate for describing the growth of a particular leaf or of the whole stand (Causton \& Venus 1982, Poorter \& Van Der Werf 1998) although the presence of 4 parameters makes this function not easy to fit.

The Richards function gives rise to a non-

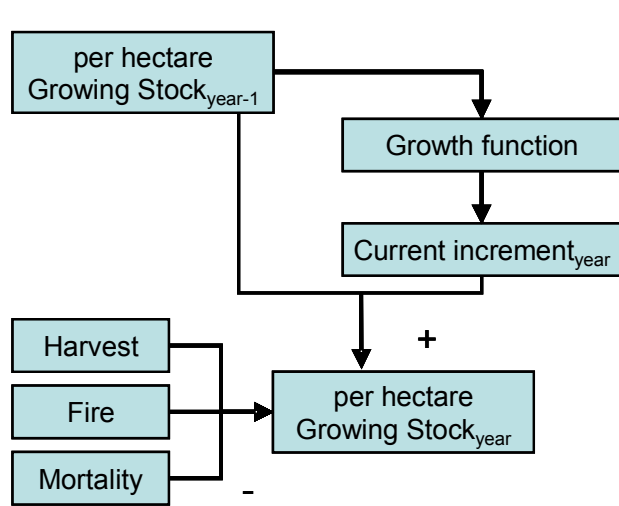

linear regression situation because the criterion of biological simplicity states that the relative growth of the attributes concerned declines in a mathematically simple manner with increasing size of attribute, but there is sufficient flexibility in the Richards function to allow for varying duration of initial, nearly constant, relative growth rates (i.e., approximation to exponential growth).

The Richards function is defined by the following equation (eqn.1):

$$
\frac{d y}{d t}=\frac{k}{v} \cdot y\left[1-\left(\frac{y}{a}\right)^{v}\right]+y_{0} \quad \begin{gathered}
\text { first } \\
\text { derivative }
\end{gathered}
$$

The analytical solution of equation 1 is the Richards growth curve (eqn. 2):

$$
y=a \cdot\left[1-e^{(\beta-k t)}\right]^{1 / v}
$$

where general constrain for parameters are: $a, k>0 ;-1 \leq v \leq \infty ; v \neq 0$.

The curve is a generalization of most used growth curves: exponential growth $(a \rightarrow \infty$, $v>0)$, logistic growth $(v>1)$, Bertalanffy function $(v=3)$ and Gompertz function $(v \rightarrow \pm \infty)$. This high flexibility is, however, combined with disadvantages as well. The parameters $(\beta, k, v)$ have a high covariance which could produce problems during nonlinear regression.

Goodness of fit have been evaluated by non-linear coefficient of determination $\mathrm{CD}$ ( or $R^{2}$ ), and performances have been evaluated against data by validation statistics according to Janssen \& Heuberger (1995). There, modelling efficiency is defined as:

$$
M E=1-\frac{\sum_{i=1}^{N}\left[\mathrm{Obs}_{i}-\mathrm{Si} \mathrm{m}_{i}\right]^{2}}{\sum_{i=1}^{N}\left[\mathrm{Obs}_{i}-\overline{\mathrm{Obs}}_{i}\right]^{2}}
$$

where $O b s_{\mathrm{i}}$ and $\operatorname{Sim}_{\mathrm{i}}$ are, respectively, the observed and the simulated values. In contrast to $\mathrm{CD}$, the modelling efficiency $(M E)$ not only measures association (or correlation) between modelled and observed data, but also their coincidence and it is sensitive to systematic deviation between model and observation. When $M E$ is close to 1 the best performances are obtained.

In the approach followed, the Richards function is fitted through data of growing stock $\left[\mathrm{m}^{3} \mathrm{ha}^{-1}\right]$ and increment $\left[\mathrm{m}^{3} \mathrm{ha}^{-1} \mathrm{y}^{-1}\right]$ obtained by the collection of Italian yield tables (Federici et al. 2001 - http://gaia.agraria.unitus.it/download/alsom.html) because it is the only one data source offorest

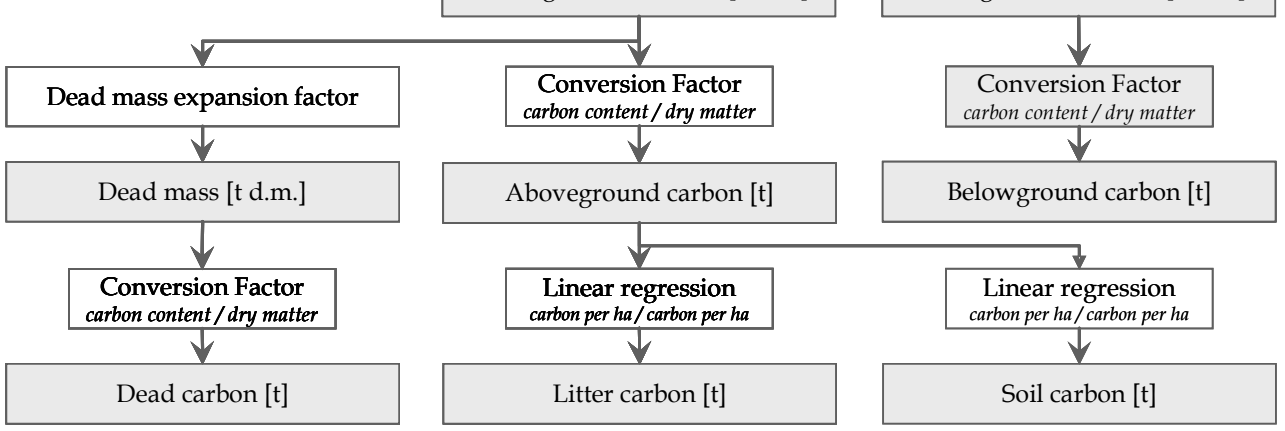

Fig. 3 - Model flowchart. 
growing stocks and current increments at national level. The independent variable $x$ represents growing stock, while the dependent variable $y$ is the correspondent current increment computed with the Richards function first derivative.

Such application of Richards function first derivative - results, generally, in a high coefficient of determination (Fig. 1), that largely decrease with the increase of the number of quality classes forming the yield table (Fig. 2).

\section{Model structure}

Using growing stock as unique driver, the model is able to estimate evolution in time of the five forest carbon pools, classified and defined according to Good Practice Guidground and belowground biomass (living biomass), dead wood and litter (dead organic matter) and soil (soil organic matter - Fig. 3).

The methodology for growing stocks assessment in the years following NFI year is described as following:

1. starting from initial growing stock volume (e.g., growing stock volume reported in the First Italian National Forest Inventory; MAF-ISAFA 1988), for each year, the current increment per hectare $\left[\mathrm{m}^{3} \mathrm{ha}^{-1} \mathrm{y}^{-1}\right]$ is computed with the derivative Richards function, for every specific forest typology;

2. for each year, growing stock per hectare ance for LULUCF (IPCC 2003): above-

$\left[\mathrm{m}^{3} \mathrm{ha}^{-1}\right]$ is computed from the previous year growing stock volume adding the calculated current increment (" $y$ " value of the derivative Richards) and subtracting losses due to harvest, mortality and fire occurred in the current year.

The process can be summarized as follows (eqn. 3):

$$
g s_{i}=\frac{g s_{i-1}+I_{i}-H_{i}-F_{i}-M_{i}\left(-D_{i}\right)}{A_{i}}
$$

in which current increment is calculated year by year by applying the derivative Richards function; and $g s_{\mathrm{i}}$ is the volume per hectare of growing stock for current year; $g s_{\mathrm{i}-1}$ is the total previous year growing stock volume; $I_{\mathrm{i}}$ is calculated as $f\left(v_{\mathrm{i}-1}\right) \cdot A_{\mathrm{i}-1}$ and is the total current increment of growing stock for current year; $f$ is the Richards function reported above; $v_{\mathrm{i}-1}$ is the previous year growing stock volume per hectare; $A_{\mathrm{i}-1}$ is the total area referred to a specific forest typology for previous year; $H_{\mathrm{i}}$ is the total amount of harvested growing stock for current year; $F_{\mathrm{i}}$ is the total amount of burned growing stock for current year; $M_{\mathrm{i}}$ is the total amount of growing stock removed by natural mortality; $D_{\mathrm{i}}$ is the total amount of growing stock removed by drain and grazing (only in the category: protective forest).

Carbon amount released by forest fires has been included in the overall assessment of carbon stocks change. Since data on the fraction of growing stock oxidised as con-

Tab. 3 - Relations: litter and soil carbon - aboveground carbon per ha.

\begin{tabular}{|c|c|c|c|}
\hline Category & Inventory typology & $\begin{array}{c}\text { Relation litter } \\
\text { Aboveground C / ha }\end{array}$ & $\begin{array}{c}\text { Relation soil } \\
\text { Aboveground C / ha }\end{array}$ \\
\hline \multirow[t]{10}{*}{ Stands } & norway spruce & $y=0.0659 x+1.5045$ & $y=0.4041 x+57.874$ \\
\hline & silver fir & $y=0.0659 x+1.5045$ & $y=0.4041 x+57.874$ \\
\hline & larches & $y=0.0659 x+1.5045$ & $y=0.4041 x+57.874$ \\
\hline & mountain pines & $y=0.0659 x+1.5045$ & $y=0.4041 x+57.874$ \\
\hline & mediterranean pines & $y=0.0659 x+1.5045$ & $y=0.4041 x+57.874$ \\
\hline & other conifers & $y=0.0659 x+1.5045$ & $y=0.4041 x+57.874$ \\
\hline & european beech & $y=-0.0299 x+9.3665$ & $y=0.9843 x+5.0746$ \\
\hline & turkey oak & $y=-0.0299 x+9.3665$ & $y=0.9843 x+5.0746$ \\
\hline & other oaks & $y=-0.0299 x+9.3665$ & $y=0.9843 x+5.0746$ \\
\hline & other broadleaves & $y=-0.0299 x+9.3665$ & $y=0.9843 x+5.0746$ \\
\hline \multirow[t]{8}{*}{ Coppices } & european beech & $y=-0.0299 x+9.3665$ & $y=0.3922 x+65.356$ \\
\hline & sweet chestnut & $y=-0.0299 x+9.3665$ & $y=0.3922 x+65.356$ \\
\hline & horbeams & $y=-0.0299 x+9.3665$ & $y=0.3922 x+65.356$ \\
\hline & other oaks & $y=-0.0299 x+9.3665$ & $y=0.3922 x+65.356$ \\
\hline & turkey oak & $y=-0.0299 x+9.3665$ & $y=0.3922 x+65.356$ \\
\hline & evergreen oaks & $y=-0.0299 x+9.3665$ & $y=0.3922 x+65.356$ \\
\hline & other broadleaves & $y=-0.0299 x+9.3665$ & $y=0.3922 x+65.356$ \\
\hline & conifers & $y=0.0659 x+1.5045$ & $y=0.4041 x+57.874$ \\
\hline \multirow[t]{6}{*}{ Plantations } & eucalyptuses coppices & $y=-0.0299 x+9.3665$ & $y=0.3922 x+65.356$ \\
\hline & other broadleaves coppices & $y=-0.0299 x+9.3665$ & $y=0.3922 x+65.356$ \\
\hline & poplars stands & $y=-0.0299 x+9.3665$ & $y=0.9843 x+5.0746$ \\
\hline & other broadleaves stands & $y=-0.0299 x+9.3665$ & $y=0.9843 x+5.0746$ \\
\hline & conifers stands & $y=0.0659 x+1.5045$ & $y=0.4041 x+57.874$ \\
\hline & others & $y=-0.0165 x+7.3285$ & $y=0.7647 x+33.638$ \\
\hline \multirow[t]{3}{*}{ Protective } & rupicolous forest & $y=-0.0165 x+7.3285$ & $y=0.7647 x+33.638$ \\
\hline & riparian forest & $y=-0.0299 x+9.3665$ & $y=0.9843 x+5.0746$ \\
\hline & shrublands & $y=-0.0299 x+9.3665$ & $y=0.3922 x+65.356$ \\
\hline
\end{tabular}

sequence of fires were not available, the most conservative hypothesis has been adopted; all growing stock of burned forest areas has been assumed to be completely oxidised and so released. Moreover, since data on forest typologies of burned areas were also not available, the total value of burned forest area coming from national statistics has been subdivided and assigned to forest typologies based on their respective weight on total national forest area. Finally, the amount of burned growing stock has been calculated multiplying average growing stock per hectare of forest typology for the assigned burned area. Assessed value has been subtracted to total growing stock of respective typology, as afore said.

Once estimated growing stock, amounts of aboveground woody tree biomass, belowground biomass and dead mass are consequently assessed.

\section{Aboveground biomass}

For every forest typology, starting from growing stock data, the amount of aboveground woody tree biomass (d.m.) [t] is estimated, for every forest typology, through the relation (eqn. 4):

Aboveground woodytree biomass $($ d.m. $)=$ $G S \cdot B E F \cdot W B D \cdot A$

where $G S$ is the volume of growing stock $\left[\mathrm{m}^{3} \mathrm{ha}^{-1}\right] ; B E F$ is the biomass expansion factor, which expands growing stock volume to volume of aboveground woody biomass; $W B D$ is the wood basic density [t d.m. $\mathrm{m}^{-3}$ f.v.]; and $A$ is the forest area occupied by a specific typology [ha].

\section{Belowground biomass}

For every forest typology, applying a Biomass Expansion Factor to growing stock data, the belowground biomass is estimated, with the following relation (eqn. 5):

\section{Belowground woody tree biomass $($ d.m. $)=$ $G S \cdot W B D \cdot R \cdot A$}

where $G S$ is the volume of growing stock $\left[\mathrm{m}^{3} \mathrm{ha}^{-1}\right] ; R$ is the root/shoot ratio, which converts growing stock biomass in belowground biomass; $W B D$ is the wood basic density [t d.m. $\mathrm{m}^{-3}$ f.v.]; $A$ is the forest area occupied by a specific typology [ha].

\section{Dead mass}

For every forest typology, the deadwood mass was assessed applying a dead mass conversion factor (DCF, in accordance with table 3.2.2 of GPG for LULUCF - IPCC 2003). The dead mass [t] is (eqn. 6):

$$
\begin{gathered}
\operatorname{Deadmass}(d . m .)= \\
G S \cdot B E W \cdot W B D \cdot D C F \cdot A
\end{gathered}
$$


where $G S$ is the volume of growing stock $\left[\mathrm{m}^{3} \mathrm{ha}^{-1}\right] ; B E F$ is the Biomass Expansion Factor which expands growing stock volume to volume of aboveground woody biomass; $W B D$ is the Wood Basic Density [t d.m. $\mathrm{m}^{-3}$ f.v.]; $D C F$ is the Dead mass Conversion Factor, which converts aboveground woody biomass in dead mass; $A$ is the forest area occupied by a specific typology.

\section{Litter}

Total litter carbon amount is estimated from the carbon amount of aboveground biomass with linear relations. Linear relations between stand biomass and litter have been reported in many forest studies (Waring \& Running 1998).

\section{Soil}

Applying linear relations, total soil carbon amount is estimated from carbon amount in aboveground biomass, following the same rationale as for litter carbon.

The carbon stocks change of living biomass (LB) is calculated according to Good Practice Guidance for LULUCF (IPCC 2003), from aboveground (AG) and belowground (BG) biomass (eqn. 7):

$$
\Delta C_{L B}=\Delta C_{A G}+\Delta C_{B G}
$$

where total amount of carbon has been obtained from biomass (d.m.), multiplying by the GPG default factor for carbon fraction equal to 0.5 .

The Dead Organic Matter (DOM) carbon pool is defined, in the GPG, as the sum of dead wood (D) and litter (L - eqn. 8):

$$
\Delta C_{D O M}=\Delta C_{D}+\Delta C_{L}
$$

The total amount of carbon for dead mass



Fig. 5 - Carbon stock changes in the five carbon pools $\left[\mathrm{Gg} \mathrm{CO}_{2}\right.$ equivalent].

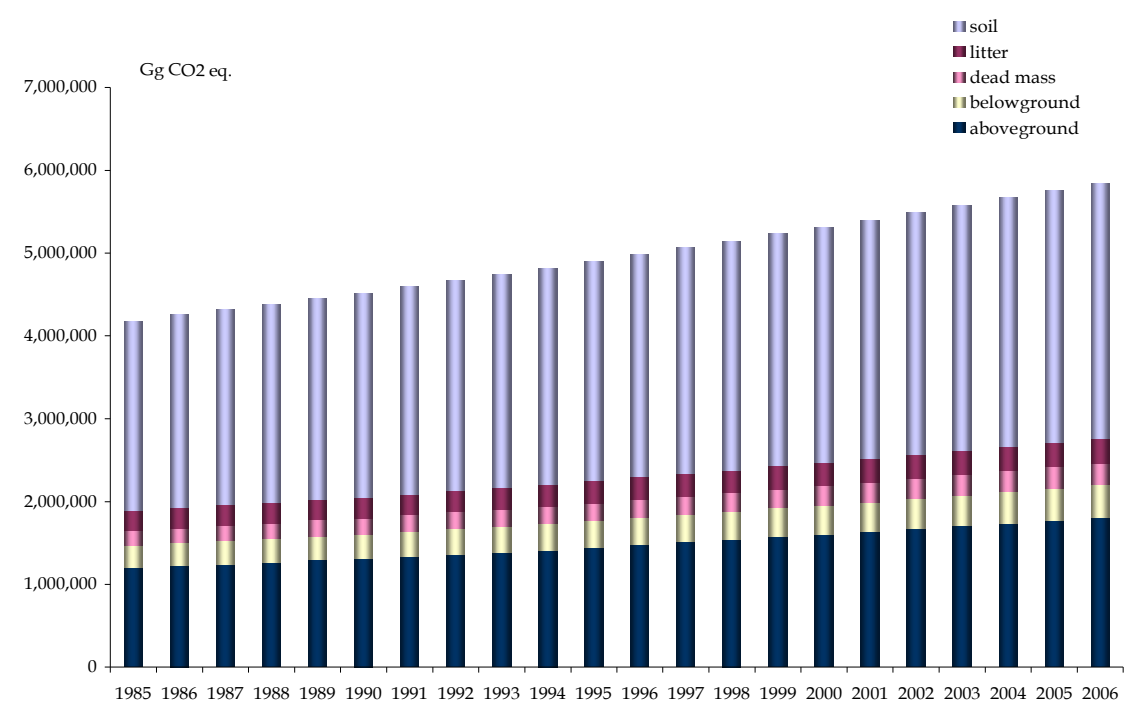

Fig. 4 - Carbon stock in the five carbon pools [ $\mathrm{Gg} \mathrm{CO}_{2}$ equivalent]. has been obtained from dead mass (d.m.), multiplying by the GPG default factor for carbon fraction equal to 0.5 .

\section{The Italian dataset}

The above-described model has been applied to the Italian dataset, to assess carbon stocks in the five forest pools for reporting year 2007 of the Italian GHG's Inventory.

The model has been applied at regional scale (NUT2) because of availability of any forest-related statistical data. Starting year of the model has been 1985 and estimates have been provided from 1986 to 2006 .

Inventory typologies are classified in 4 main categories: Stands, Coppices, Plantations and Protective Forests: (i) Stands: norway spruce, silver fir, larches, mountain pines, mediterranean pines, other conifers, european beech, turkey oak, other oaks, other broadleaves. (ii) Coppices: european beech, sweet chestnut, hornbeams, other oaks, turkey oak, evergreen oaks, other broadleaves, conifers. (iii) Plantations: eucalyptuses coppices, other broadleaves coppices, poplar stands, other broadleaves stands, conifers stands, others. (iv) Protective Forests: rupicolous forest, riparian forests, shrublands.

Model input data for forest area, detailed by region and by forest typologies, come from the First Italian National Forest Inventory (MAF-ISAFA 1988) and from the Second Italian National Forest Inventory. Forest area estimation for 1990 has been done through a linear interpolation between the 1985 and 2002 data (pers. comm., MAFISAFA 2004). By assuming that defined trend may well represent near future, it was possible to extrapolate data for 2006.

For each of the five carbon pools, dataset and factors are set as explained in the following sections.

\section{Woody aboveground biomass}

Model input data of growing stocks for the start year (1985), detailed by region and by forest typologies come from the First Italian National Forest Inventory.

The average rate of mortality used for calculation have been 0.0116 , concerning evergreen forests, and 0.0117 , for deciduous forests, according to GPG for LULUCF (IPCC 2003).

The rate of draining and grazing, applied to protective forest, has been set as 3\% following a personal judgement because total absence of referable data.

Total commercial harvested wood, for construction and energy purposes, has been ob- 
Tab. 4 - Carbon stocks in the five carbon pools [ $\mathrm{Gg} \mathrm{CO}_{2}$ equivalent].

\begin{tabular}{ccccccc}
\hline \multirow{2}{*}{ Year } & \multicolumn{2}{c}{ living biomass } & \multicolumn{2}{c}{ dead organic matter } & $\begin{array}{c}\text { soil organic } \\
\text { matter }\end{array}$ \\
\cline { 2 - 5 } & aboveground & belowground & dead mass & litter & Soil \\
\hline 1985 & 1195445 & 273629 & 180432 & 237858 & 2296283 & 4183646 \\
1986 & 1219454 & 278155 & 183507 & 240877 & 2331502 & 4253495 \\
1987 & 1241906 & 282299 & 186357 & 243926 & 2365635 & 4320122 \\
1988 & 1263786 & 286372 & 189130 & 247061 & 2399733 & 4386082 \\
1989 & 1288949 & 291217 & 192312 & 250061 & 2435865 & 4458404 \\
1990 & 1307136 & 294627 & 194425 & 253141 & 2468297 & 4517626 \\
1991 & 1336836 & 300486 & 198270 & 256090 & 2506809 & 4598490 \\
1992 & 1364584 & 305907 & 201852 & 259086 & 2544270 & 4675700 \\
1993 & 1385098 & 309730 & 204595 & 262246 & 2576800 & 4738468 \\
1994 & 1414023 & 315450 & 208465 & 265223 & 2614371 & 4817532 \\
1995 & 1445453 & 321838 & 212575 & 268160 & 2653922 & 4901947 \\
1996 & 1478567 & 328579 & 217010 & 271103 & 2694039 & 4989297 \\
1997 & 1507848 & 334508 & 220890 & 274093 & 2731941 & 5069279 \\
1998 & 1536363 & 340190 & 224707 & 277042 & 2768860 & 5147161 \\
1999 & 1568504 & 346799 & 229142 & 280018 & 2808277 & 5232741 \\
2000 & 1597791 & 352703 & 233178 & 283057 & 2845515 & 5312244 \\
2001 & 1631400 & 359586 & 237801 & 286044 & 2885499 & 5400330 \\
2002 & 1668344 & 367203 & 242900 & 288986 & 2927452 & 5494885 \\
2003 & 1700073 & 373692 & 247282 & 291995 & 2966507 & 5579550 \\
2004 & 1735805 & 381056 & 252229 & 294992 & 3008005 & 5672083 \\
2005 & 1771367 & 388414 & 257127 & 297971 & 3049532 & 5764411 \\
2006 & 1803549 & 395100 & 261601 & 300992 & 3088758 & 5850001 \\
\hline
\end{tabular}

tained from national statistics (ISTAT 2008a); even if data on biomass removed in commercial harvest published by ISTAT are probably underestimated, particularly concerning fuelwood consumption (ARPA Lombardia 2007). Data of wood use for construction and energy purposes, reported in $\mathrm{m}^{3}$, are disaggregated at NUT2 level, in sec- toral statistics (ISTAT 2008a, 2008b, 2008c) for each forest typology, using preliminary or at NUT1 level for coppices and high results of the RiselvItalia Project carried out forests in national statistics. These figures by ISAFA (ISAFA 2004), as follows:

have been subtracted, as losses, to growing - for broadleaves and pines with large stock volume, as mentioned above.

Biomass Expansion Factors for conversions from growing stock volume to volume of aboveground biomass have been derived
- for broadleaves and pines with large
crown: starting from stump, volume of whole woody biomass over bark up to 3 $\mathrm{cm}$ of diameter of all trees with diameter at breast height $\geq 3 \mathrm{~cm}$;

Tab. 5 - Carbon stock changes in the five carbon pools $\left[\mathrm{Gg} \mathrm{CO}_{2}\right.$ equivalent].

\begin{tabular}{|c|c|c|c|c|c|c|}
\hline \multirow{2}{*}{ Year } & \multicolumn{2}{|c|}{ living biomass } & \multicolumn{2}{|c|}{ dead organic matter } & \multirow{2}{*}{$\begin{array}{c}\begin{array}{c}\text { soil organic } \\
\text { matter }\end{array} \\
\text { soil }\end{array}$} & \multirow{2}{*}{ total } \\
\hline & aboveground & belowground & dead mass & litter & & \\
\hline 1986 & 24009 & 4526 & 3076 & 3019 & 35219 & 69848 \\
\hline 1987 & 22452 & 4145 & 2849 & 3049 & 34133 & 66627 \\
\hline 1988 & 21881 & 4073 & 2773 & 3135 & 34098 & 65960 \\
\hline 1989 & 25163 & 4844 & 3183 & 3001 & 36132 & 72322 \\
\hline 1990 & 18187 & 3410 & 2113 & 3079 & 32432 & 59222 \\
\hline 1991 & 29700 & 5859 & 3845 & 2949 & 38512 & 80864 \\
\hline 1992 & 27748 & 5422 & 3582 & 2996 & 37462 & 77209 \\
\hline 1993 & 20514 & 3822 & 2743 & 3159 & 32529 & 62768 \\
\hline 1994 & 28925 & 5721 & 3870 & 2977 & 37572 & 79064 \\
\hline 1995 & 31430 & 6388 & 4110 & 2937 & 39550 & 84415 \\
\hline 1996 & 33114 & 6742 & 4435 & 2943 & 40117 & 87350 \\
\hline 1997 & 29281 & 5928 & 3880 & 2991 & 37902 & 79982 \\
\hline 1998 & 28515 & 5682 & 3817 & 2949 & 36919 & 77882 \\
\hline 1999 & 32141 & 6610 & 4436 & 2976 & 39417 & 85580 \\
\hline 2000 & 29287 & 5903 & 4036 & 3039 & 37238 & 79503 \\
\hline 2001 & 33609 & 6883 & 4623 & 2986 & 39984 & 88086 \\
\hline 2002 & 36945 & 7617 & 5099 & 2942 & 41952 & 94555 \\
\hline 2003 & 31729 & 6489 & 4383 & 3010 & 39055 & 84665 \\
\hline 2004 & 35732 & 7364 & 4947 & 2996 & 41498 & 92538 \\
\hline 2005 & 35562 & 7358 & 4897 & 2979 & 41526 & 92323 \\
\hline 2006 & 32182 & 6686 & 4474 & 3021 & 39227 & 85590 \\
\hline
\end{tabular}


- for conifers: starting from stump, wood volume of stem over bark up to $3 \mathrm{~cm}$ of diameter of all trees with diameter at breast height $\geq 3 \mathrm{~cm}$.

Wood Basic Densities for conversions from fresh volume to dry weight have been derived for each forest typology, from Giordano 1980. In Tab. 2 BEF's and WBD's are reported.

\section{Belowground biomass}

Also in this case, the values for root/shoot ratio $R s$, reported in Tab. 2, were derived for each forest typology, in the same way as for aboveground biomass. Values refer to all living biomass of live roots; fine roots of less than (suggested) $2 \mathrm{~mm}$ diameter are often excluded because these often cannot be distinguished empirically from soil organic matter or litter.

\section{Dead mass}

The deadwood mass was assessed applying a dead mass conversion factor (DCF of respectively 0.2 for evergreen forests and 0.14 for deciduous forests, as reported in Tab. 3.2.2 of GPG - IPCC 2003).

\section{Litter}

It includes all non-living biomass with a diameter less than a minimum diameter chosen by the country for lying dead (for example $10 \mathrm{~cm}$ ), in various states of decomposition above the mineral or organic soil This includes the litter, fumic, and humic layers. Live fine roots (of less than the suggested diameter limit for below-ground biomass) are included in litter where they cannot be distinguished from it empirically.

Up to now we do not have a full comprehensive data set to establish a more proper biophysical relation for Italian forests. But collection of data in the Italian new national

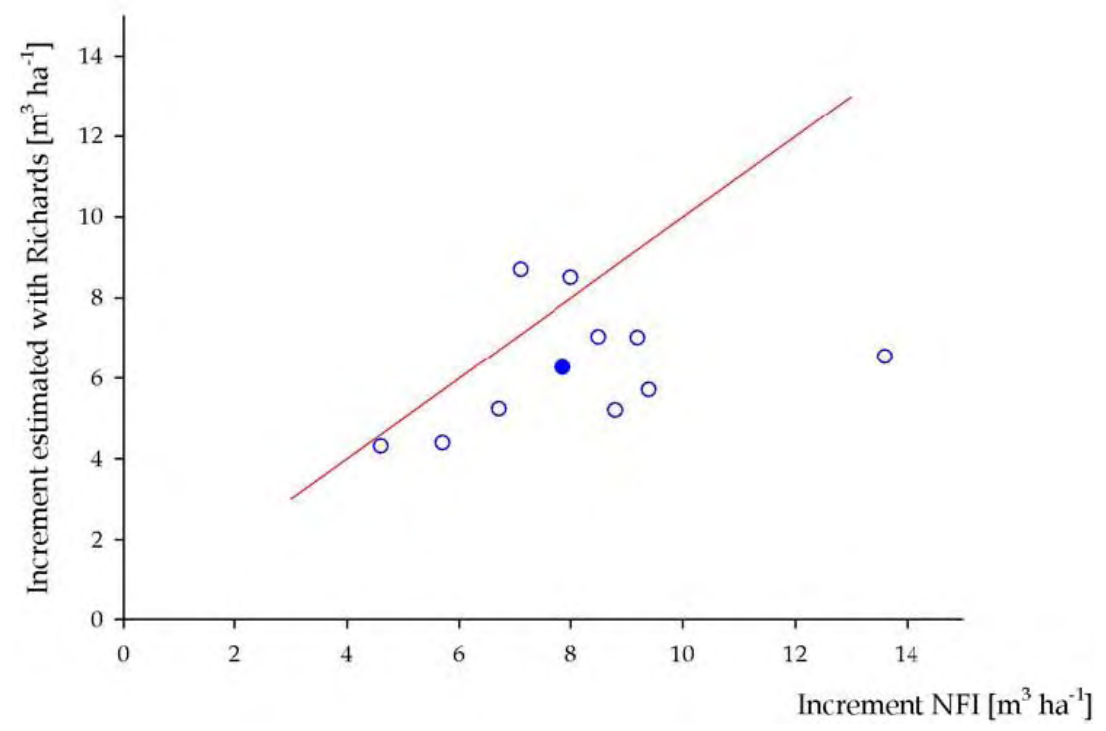

Fig. 6 - Current increment reported on NFI vs current increment estimated with Richards. (stands). forest inventory should allow to analyze the relationship and to choose most appropriate mathematical representation. For present work we have used the results of the European project CANIF (http://www.bgcjena.mpg.de/bgc-processes/research/Schulze_Euro_CANIF.html\#contents) which has reported such relations for a number of European forest stands. The total litter carbon amount has been estimated from aboveground carbon amount with linear relations differentiated per forestry use: stands (resinous, broadleaves, mixed stands) and coppices (Tab. 3).

Soil

To this purpose we have used data coming from a number of permanent plots, distributed in several forest typologies, within the project CONECOFOR (http://www.corpoforestale.it/wai/serviziattivita/CONECOFOR/index.htm) of the Italian Ministry of Agri-

Tab. 6 - NFI's and estimated current increment values for different forest typologies

\begin{tabular}{lcc}
\hline \multicolumn{1}{c}{ Forest typology } & $\begin{array}{c}\text { current increment reported } \\
\text { in the } \mathbf{1}^{\text {st }} \mathbf{~ N F I ~ ( 1 9 8 5 ) ~}\end{array}$ & $\begin{array}{c}\text { current increment estimated } \\
\text { with Richards functions }\end{array}$ \\
\hline \multicolumn{1}{c}{ high stands } & $\mathbf{m}^{\mathbf{3}} \mathbf{h a}^{-\mathbf{1}}$ & $\mathbf{~ m}^{\mathbf{3}} \mathbf{h a}^{\mathbf{- 1}}$ \\
\hline norway spruce & 9.4 & 5.7 \\
silver fir & 9.2 & 7.0 \\
larches & 5.7 & 4.4 \\
mountain pines & 8 & 8.5 \\
mediterranean pines & 7.1 & 8.7 \\
other conifers & 13.6 & 6.5 \\
european beech & 8.5 & 7.0 \\
turkey oak & 6.7 & 5.2 \\
other oaks & 4.6 & 4.3 \\
other broadleaves & 8.8 & 5.2 \\
average & 7.9 & 6.3 \\
\hline
\end{tabular}

culture and Forestry, which provided data on stand biomass and soil carbon. Per forestry use: stands (resinous, broadleaves, mixed stands) and coppices, total soil carbon amount $\left[\mathrm{t} \mathrm{C} \mathrm{ha} \mathrm{C}^{-1}\right]$ has been estimated from carbon amount of total woody aboveground biomass [ $\mathrm{t} \mathrm{C} \mathrm{ha}{ }^{-1}$, with linear relations. In Tab. 3 the used relations have been reported.

\section{Results and discussion}

In the reported case of study, the For-est model has been applied to Italian dataset, in order to provide estimates of carbon stocks changes in the five forest pools: aboveground, belowground and dead mass, soil and litter (Fig. 4). In the following tables (Tab. 4 and Tab. 5), carbon stocks in the above mentioned pools and carbon stock changes are shown.

It can be noted that in 2006 the Italian total carbon stock in forest sector amounts to about $5.8 \mathrm{Gt}^{\mathrm{CO}_{2}}$ with the largest pool constituted by soil carbon. The ratio of aboveground biomass to soil carbon is about 0.58 which is higher than the one (circa $45 \%$ ) calculated for other European countries from the data reported in the FAO - Global Forest Resources Assessment (UN/ECE-FAO 2005). The three other pools (below ground, dead wood and litter) are almost equivalent and amount to about $7 \%, 4 \%$ and $5 \%$ of total, respectively.

The increasing trend of the five pools reflects in this case the expansion of forest areas which occurred in the period 1986 2006.

By contrast stock changes in aboveground biomass are comparable with changes in soil carbon stocks (Fig. 5). The values showed in Tab. 5, if reported at the stand level shows an average 1986-2006 accumulation rate of $7.94 \mathrm{t} \mathrm{CO}_{2} \mathrm{ha}^{-1} \mathrm{y}^{-1}$ (living biomass $3.47 \mathrm{t} \mathrm{CO}_{2}$ $\mathrm{ha}^{-1} \mathrm{y}^{-1}$; dead organic matter: $0.69 \mathrm{t} \mathrm{CO}_{2} \mathrm{ha}^{-1}$ $\mathrm{y}^{-1}$; soil: $\left.3.79 \mathrm{t} \mathrm{CO}_{2} \mathrm{ha}^{-1} \mathrm{y}^{-1}\right)$. In general, this result seems to show some overestimation of 
Tab. 7 - Relations for assessing uncertainties of $\mathrm{C}$ pools.

\begin{tabular}{|c|c|}
\hline Carbon pool & Relation for uncertainty assessing \\
\hline Aboveground & $\mathrm{E}_{\mathrm{AB}_{-} 1985}=\left(\mathrm{E}_{\mathrm{NFN}}^{2}+\mathrm{E}_{\mathrm{BEF}}^{2}+\mathrm{E}_{\mathrm{BD}}^{2}+\mathrm{E}_{\mathrm{CF}}^{2}\right)^{0.5}$ \\
\hline Belowground & $\mathrm{E}_{\mathrm{BG} \_1985}=\left(\mathrm{E}_{\mathrm{NFI}}^{2}+\mathrm{E}_{\mathrm{R}}^{2}+\mathrm{E}_{\mathrm{BD}}{ }^{2}+\mathrm{E}_{\mathrm{CF}}{ }^{2}\right)^{0.5}$ \\
\hline Dead mass & $\mathrm{E}_{\mathrm{D}_{1} \_985}=\left(\mathrm{E}_{\mathrm{AG} \_1985}{ }^{2}+\mathrm{E}_{\text {DCF_1985 }}{ }^{2}\right)^{0.5}$ \\
\hline Litter & $\mathrm{E}_{\mathrm{L}_{\_} 1985}=\left(\mathrm{E}_{\mathrm{LS} \_1985}{ }^{2}+\mathrm{E}_{\mathrm{LR} \_s}{ }^{2}\right)^{0.5}$ \\
\hline Soil & $\mathrm{E}_{\mathrm{S}_{\_} 1985}=\left(\mathrm{E}_{\mathrm{SS} \_1985}{ }^{2}+\mathrm{E}_{\mathrm{SR} \_s_{\mathrm{S}}}\right)^{0.5}$ \\
\hline
\end{tabular}

parison between measured and estimated values is only feasible for high stands, since only for this silvicultural system the values of current increments are reported in the first NFI.

In Fig. 6, current increments estimated with the Richards function are plotted against current increment data obtained by the first Italian NFI. Because wide majority of the points are in soil carbon changes, and it is due also to the fact that when new forest area is added then, automatically, the whole soil carbon stock of such area is added to the total resulting in an increase of total carbon stock that is actually no more than a shifting of stocks from one land use category (i.e., grassland) to another (i.e., forest land).

Tab. 6 shows values of current increment reported on National Forest Inventory (MAF 1986) for different forest typologies. In the same table, the values of current increment assessed by Richards functions are also reported, calibrated on yield tables data. Com-

Tab. 9 - Uncertainties related to carbon pools and overall uncertainty for year 1985 .

$\begin{array}{ll}\text { Aboveground biomass } & \mathrm{E}_{\mathrm{AG}} 42.59 \% \\ \text { Belowground biomass } & \mathrm{E}_{\mathrm{BG}} 42.59 \% \\ \text { Dead mass } & \mathrm{E}_{\mathrm{D}} 52.10 \% \\ \text { Litter } & \mathrm{E}_{\mathrm{L}} 161.22 \% \\ \text { Soil } & \mathrm{E}_{\mathrm{S}} 152.05 \% \\ \text { Overall uncertainty } & \mathrm{E}_{1985} 84.91 \%\end{array}$

Tab. 10 - Overall uncertainties 1985 - 2006.

\begin{tabular}{cc} 
Year & Perc. \\
\hline 1985 & $84.91 \%$ \\
1986 & $84.81 \%$ \\
1987 & $88.09 \%$ \\
1988 & $88.32 \%$ \\
1989 & $88.26 \%$ \\
1990 & $88.25 \%$ \\
1991 & $88.15 \%$ \\
1992 & $87.97 \%$ \\
1993 & $87.93 \%$ \\
1994 & $87.84 \%$ \\
1995 & $87.65 \%$ \\
1996 & $87.46 \%$ \\
1997 & $87.32 \%$ \\
1998 & $87.22 \%$ \\
1999 & $87.07 \%$ \\
2000 & $86.93 \%$ \\
2001 & $86.77 \%$ \\
2002 & $86.57 \%$ \\
2003 & $86.41 \%$ \\
2004 & $86.27 \%$ \\
2005 & $86.09 \%$ \\
2006 & $85.97 \%$ \\
\hline
\end{tabular}
the lower half of Cartesian field, it is possible to state that the model shows a systematic underestimation of current increments (in particular the estimated average value is $20 \%$ smaller).

The mismatch between the estimated and reported NFI data is likely to be caused by a general disagreement between yield tables and the real average quality of forest sites in the country. The Richards function was parametrised using all yield tables quality classes, on average, without weighting different contributes of different classes.

Moreover, the available yield tables are somewhat outdated since they were compiled mainly during the years 1950-1970. Nowadays a higher current increment than in the past is most likely, as confirmed in other countries like Germany (see http://www.bundeswaldinventur.de) due to increased temperatures, atmospheric $\mathrm{CO}_{2}$ concentration and nitrogen deposition (Magnani et al. 2007), as well as changes in forest management, based also on the conclusion of the IPCC expert meeting on current scientific understanding of the processes affecting terrestrial carbon stocks and human influences upon them (Geneva, Switzerland 21-23 July 2003).

Beside to the possible underestimate of current increment, it should be noted that losses by harvested wood are underestimated too, particularly concerning fuelwood consumption. In the estimation process of growing stock time series, a sort of compensation is very likely to occur between underestimated current increment and underestimated harvesting.

Further improvements in refining current increment estimate will be possible when more basic data and information from the second national forest inventory will be available.

\section{Uncertainty}

To assess overall uncertainty related to estimates for years 1990-2006, we followed the GPG Tier 1 Approach. The uncertainty linked to the year 1985, when first National

$$
E_{1985}=\frac{\sqrt{\sum_{i}\left(E_{i_{1985}} \cdot V_{i_{1985}}\right)^{2}}}{\sum_{i}\left|V_{i_{1985}}\right|}
$$
Forest Inventory was carried out, was calcu-
Tab. 8 - Carbon stocks and uncertainties for year 1985 and current increment related uncertainty. (a) The current increment is estimated by the Richards function (first derivative); uncertainty has been assessed considering the standard error of the linear regression between the estimated values and the corresponding current increment values reported in the National Forest Inventory. (b) Good Practice Guidance default value (IPCC 2003).

\begin{tabular}{|c|c|c|}
\hline \multirow{5}{*}{$\begin{array}{l}\text { Carbon } \\
\text { stocks } \mathrm{t} \text { and } \\
\mathrm{CO}_{2} \text { eq. ha }{ }^{-1}\end{array}$} & Aboveground biomass & $\mathrm{V}_{\mathrm{AG}} 137.8$ \\
\hline & Belowground biomass & $\mathrm{V}_{\mathrm{BG}} 31.5$ \\
\hline & Dead mass & $\mathrm{V}_{\mathrm{D}} 20.8$ \\
\hline & Litter & $V_{L} 27.4$ \\
\hline & Soil & $\mathrm{V}_{\mathrm{s}} 264.7$ \\
\hline \multirow[t]{13}{*}{ Uncertainty } & Growing stock & $\mathrm{E}_{\mathrm{NFI}} 3.2 \%$ \\
\hline & $\begin{array}{l}\text { Current increment } \\
\text { (Richards) }^{(\mathrm{a})}\end{array}$ & $\mathrm{E}_{\mathrm{NFI}} 51.6 \%$ \\
\hline & Harvest $^{(\mathrm{b})}$ & $\mathrm{E}_{\mathrm{H}} 30 \%$ \\
\hline & Fire $^{(\mathrm{b})}$ & $\mathrm{E}_{\mathrm{F}} 30 \%$ \\
\hline & Drain and grazing & $E_{D} 30 \%$ \\
\hline & Mortality & $\mathrm{E}_{\mathrm{M}} 30 \%$ \\
\hline & $\mathrm{BEF}$ & $\mathrm{E}_{\mathrm{BEF} 1} 30 \%$ \\
\hline & $\mathrm{R}$ & $\mathrm{E}_{\mathrm{BEF} 2} 30 \%$ \\
\hline & DCF & $\mathrm{E}_{\mathrm{DEF}} 30 \%$ \\
\hline & Litter (stock + regression) & $E_{L} 161 \%$ \\
\hline & Soil (stock + regression) & $E_{S} 152 \%$ \\
\hline & Basic Density & $\mathrm{E}_{\mathrm{BD}} 30 \%$ \\
\hline & C Conversion Factor & $E_{C F} 2 \%$ \\
\hline
\end{tabular}

lated with the relation (eqn. 9):

where overall uncertainty $E$ is expressed by the terms $V_{\mathrm{i}}$ indicating each of the carbon stocks of the five pools for the year 1985 ( $i=$ AG: aboveground, BG: belowground, D: dead mass, L: litter, S: soil), while, with letter $\mathrm{E}$, related uncertainties have been indicated. Tab. 7 shows the equations for assessing the overall uncertainties associated to the carbon pools.

Terminology for aboveground: $E_{\mathrm{NFI}}=$ uncertainty associated to growing stock data given by the first National Forest Inventory; $E_{\mathrm{BF}}=$ uncertainty related to biomass expansion factors for aboveground biomass; $E_{\mathrm{BD}}=$ uncertainty of the basic density; $E_{\mathrm{CF}}=$ uncertainty of the conversion factor, where GPG default values for uncertainty assessment have been used (IPCC 2003).

Terminology for belowground: $E_{\mathrm{R}}=$ uncertainty of root-shoot-ratio taken from GPG default. Concerning dead mass relation, $E_{\mathrm{DCF}}$ $=$ uncertainty of dead mass expansion factor, taken from GPG default; $E_{\mathrm{LS} 1985}$ and $E_{\mathrm{SS} \_1985}$ $=$ uncertainties related to litter and soil carbon stock data taken from CANIF project and CONECOFOR Programme, respectively. Finally, the terms $E_{L_{-1} 1985}$ and $E_{S_{R} \_1985}$ are defined as uncertainties related to linear regressions used to assessing litter and soil carbon stocks. Tab. 8 shows the values of carbon stocks in the five pools for year 1985, with the associated uncertainties.

Tab. 9 shows the uncertainties related to in- 
Tab. 11 - Comparison between modelized and NFI preliminary 2006 aboveground carbon stock.

\begin{tabular}{cc}
\hline $\begin{array}{c}\text { NFI aboveground } \\
\text { carbon stock } \\
\text { (tC) }\end{array}$ & $\begin{array}{c}\text { For-est model } \\
\text { related to 2006 } \\
\text { (tC) }\end{array}$ \\
\hline 486018500 & 491877087 \\
\hline
\end{tabular}

dividual carbon pools and the overall uncertainty for 1985 , as based on the equations in Tab. 7.

The overall uncertainty related to 1985 (year of the first National Forest Inventory) was propagated until 2006, following the Tier 1 approach.

The equations for the year following to 1985 are similar to the one for the 1985 uncertainty estimate, apart from terms linked to aboveground biomass: the biomass increment was computed by the methodology described in Model structure paragraph; in consequence, the related uncertainty, e.g., for 1986 , is expressed by the following formula (eqn. 10):

$$
\begin{gathered}
\hat{E}_{1985}=\frac{\sqrt{\sum_{i}\left(E_{i} \cdot V_{i}\right)^{2}}}{\left|V_{N F I}+V_{I}-V_{H}-V_{F}-V_{D}-V_{M O R}\right|} \\
E_{A G_{1985}}=\sqrt{\hat{E}_{1985}^{2}+E_{B E F}^{2}+E_{B D}^{2}+E_{C F}^{2}}
\end{gathered}
$$

where $i=\mathrm{NFI}, \mathrm{I}, \mathrm{H}, \mathrm{F}, \mathrm{D}, \mathrm{M}$.

Following Tier 1 approach and the above mentioned methodology, the overall uncertainty in the estimates produced by the described model has been quantified; in Tab. 10 the uncertainties of the $1985-2006$ period are reported.

The overall uncertainty in the model estimates between 1985 and 2006 was assessed with the following relation (eqn. 11):

$$
E_{1985-2006}=\frac{\sqrt{\left(E_{1985} V_{1985}\right)^{2}+\left(E_{2006} V_{2006}\right)^{2}}}{\left|V_{1985}+V_{2006}\right|}
$$

where terms $V_{1985}$ and $V_{2006}$ represent growing stocks in $\left[\mathrm{m}^{3} \mathrm{ha}^{-1} \mathrm{CO}_{2}\right.$ eq], $E$ the uncertainties in the respective years. The overall uncertainty related to the period $1985-2006$ is equal to $60.5 \%$.

However, on May $29^{\text {th }} 2007$, during a national workshop on forest statistics, the preliminary data of the new NFI regarding to the 2006 aboveground carbon stock of the whole Italian forest land area were presented. A comparison between our estimate and the preliminary NFI data results in $1.2 \%$ difference (Tab. 11)

\section{Conclusions}

The proposed approach has provided both a reanalysis of the Italian forest sector carbon stock changes in accordance with UNFCCC requirements and estimates of carbon stock changes for years between national forest inventories.

The use of an age-independent relationship for deriving forest growth increment, from growing stocks has been proven more useful than a classical age-growth relationship.

In particular, the approach allows deriving from the growing stock the other carbon budget components, which are usually difficult to obtain, or for which detailed process based models are still far from being operational. Using a single input like growing stock, which is regularly derived from NFI, is particularly useful: it is directly assessed and can more easily be verified by different methodologies like verification plots or remote sensing techniques.

Based on our novel approach, using NFI data of 1985 and including the new forest areas estimates of 2004 (pers. comm., MAFISAFA 2004), we calculate an overall carbon stock change for Italian forest in 2006 in the range $85 \mathrm{Mt} \mathrm{CO}_{2}$. This estimate is rather conservative since the approach based on an overall Richard function approximation tends to underestimate the observed increment by NFI.

Improvements of the above mentioned approach could be driven by the web-based "AFOLU-Clearinghouse for Policy-ScienceData" under development by JRC, especially with regard to its European level databases of allometric biomass \& carbon factors, yield tables and forest inventories (see http://afoludata.jrc.it/carboinvent/ciintro.cfm). The approach described above in combination with such database will improve quality control and quality assurance routines (e.g., verification, cross-checking) for national GHG inventories and will help in gap-filling of the forestry sector in the EC-Inventory.

Finally, it is worth to note that data produced by this methodology have been successfully used by the Italian government for the renegotiation of the Italian cap for the forest management activity under Article 3.4 of the Kyoto Protocol (FCCC/KP/CMP/2006/10/Add.1 - Decision 8/CMP.2, Forest management under Article 3, paragraph 4, of the Kyoto Protocol: Italy). A fundamental step in the renegotiation process has been the peer review of data and methodologies by the UNFCCC experts, resulting in no major findings.

The Italian cap passes from $0.18 \mathrm{Mt} \mathrm{C}$ to $2.78 \mathrm{Mt} \mathrm{C}$, with a strong impact on the economic value associated to the Italian forest, being an incentive in the conservation and sustainable management of the forest areas.

\section{References}

ARPA Lombardia (2007). Stima dei consumi di legna da ardere per riscaldamento ed uso domestico in Italia, Rapporto Finale. ARPA Lombardia,
Milano.

Atta-Boateng J, Moser JW (2000). A compatible growth and yield model for the management of mixed tropical rain forest. Can. J. For. Res. 30: 311-323.

Birch CPD (1999). A New Generalized Logistic Sigmoid Growth Equation Compared with the Richards Growth Equation. Annals of Botany 83: 713-723.

Chrimes D (2004). Stand development and regeneration dynamics of managed uneven-aged Picea abies forests in boreal Sweden. Doctoral disseration, Dept. of Silviculture, SLU. Acta Universitatis agriculturae Sueciae. Silvestria vol. 304. ISSN 1401-6230, ISBN 91-576-6538-9.

Causton DR, Venus JC (1982). The Biometry of Plant Growth. Edward Arnold, USA.

Damgaard C (1998). Plant Competition Experiments: Testing Hypotheses and Estimating the Probability of Coexistence. Ecology 79 (5): 1760-1767.

Damgaard C (1999). A test of asymmetric competition in plant monocultures using maximum likelihood function of a simple growth model. Ecological Modelling 116: 285-292.

Damgaard C, Weiner J, Nagashima H (2002). Modelling individual growth and competition in plant populations: growth curves of Chenopodium album at two densities. Journal of Ecology 90: 666-671.

Duerr WA, Gevorkiantz SR (1938). Growth prediction and site determination in uneven-aged timber stands. Journal of Agricoltural Research 56 (2): 81-98.

Federici S, Quaratino R, Papale D, Tulipano S, Valentini R (2001). Sistema informatico delle Tavole Alsometriche d'Italia, DiSAFRi - Università degli Studi della Tuscia. [online] URL: http://gaia.agraria.unitus.it

Garcia O (1979). Modelling stand development with stochastic differential equations. In: Mensuration for Management Planning of Exotic Forest Plantations, FRI Symposium (Elliot DA ed). N.Z. Forest Serv., Rotorua, New Zealand.

Garcia O (1983). A stochastic differential equation model for the height growth of forest stands. Biometrics 39: 1059-1072.

Garcia O (1993). Stand growth models: Theory and practice. In: Advancement in Forest Inventory and Forest Management Sciences. Proceedings of the IUFRO Seoul Conference. Forestry Research Institute of the Republic of Korea, pp. 22-45.

UN/ECE-FAO (2005). Global Forest Resources Assessment 2005. Main Report Italy - Country Report, UN/ECE- FAO.

Giordano G (1980). Tecnologia del legno. Hoepli, Milano.

IPCC (2000). Good Practice Guidance and Uncertainty Management in National Greenhouse Gas Inventories. IPCC National Greenhouse Gas Inventories Programme, Technical Support Unit, Hayama, Kanagawa, Japan.

IPCC (2003). Good Practice Guidance for Land Use, Land-Use Change and Forestry. IPCC Technical Support Unit, Kanagawa, Japan. 
ISAFA (2004). RiselvItalia Project. [online] URL: http://www.ricercaforestale.it/riselvitalia/index.htm.

ISTAT (2008a). Statistiche forestali. Istituto $\mathrm{Na}$ zionale di statistica, Roma.

ISTAT (2008b). Statistiche dell'agricoltura. Istituto Nazionale di statistica, Roma.

ISTAT (2008c). Annuario Statistico Italiano. Istituto Nazionale di statistica, Roma.

Janssen PHM, Heuberger PSC (1995). Calibration of process oriented models. Ecological Modelling 83: 55-66.

Lähde E, Laiho O, Norokorpi Y, Saksa T (1994). Structure and yield of all-sized and even-sized conifer-dominated stands on fertile sites. Ann. Sci. For. 51: 97-109.

Khatouri M, Dennis B (1990). Growth-and-yield model for uneven-aged Cedrus atlantica stands in Morocco. Forest Ecology and Management 36: 253-266.

Kolström T (1993). Modelling the development of an uneven-aged stand of Picea abies. Scandinavian Journal of Forest Research 8: 373-383.

Langsaeter A (1944). Om tynning i enaldret granog furuskog, Referat: Produktionsuntersuchungen von Fichtenwald. Medd. Det norske Skogforsoksvesen 8: 131-216.
MAF-ISAFA (1988). Inventario Forestale Nazionale. Sintesi metodologica e risultati. Ministero dell'Agricoltura e delle foreste. Istituto Sperimentale per l'assestamento forestale e per l'Alpicoltura, Trento.

Magnani F, Mencuccini M, Borghetti M, Berbigier P, Berninger F, Delzon S, Grelle A, Hari P, Jarvis PG, Kolari P, Kowalski AS, Lankreijer H, Law BE, Lindroth A, Loustau D, Manca G, Moncrieff JB, Rayment M, Tedeschi V, Valentini R, Grace J (2007). The human footprint in the carbon cycle of temperate and boreal forests. Nature 447: 848-850.

Masera OR, Garza-Caligaris JF, Kanninen M, Karjalainen T, Liski J, Nabuurs GJ, Pussinen A, de Jong BHJ, Mohren GMJ (2003). Modeling carbon sequestration in afforestation, agroforestry and forest management projects: the CO2FIX V.2 approach. Ecological Modelling 164: 177-199.

Moser JW (1972). Dynamics of an uneven-aged forest stand. Forest Science 18: 184-191.

Moser JW, Hall OF (1969). Deriving growth and yield functions for uneven-aged forest stands. Forest Science 15: 183-188.

Poorter H, Van Der Werf A (1998). Is inherent variation in RGR determined by LAR at low irra- diance and by NAR at high irradiance? A review of herbaceous species. In: Inherent Variation in Plant Growth; Physiological Mechanisms and Ecological Consequences (Lambers H, Poorter H, van Vuuren MMI eds). Backhuys Publishers, Leiden, The Netherlands, pp. 309-336.

Richards FJ (1959). A flexible growth curve for empirical use. Journal of Experimental Botany 10: $290-300$.

Rennolls K (1995). Forest height growth modelling. Forest Ecology and Management 71: 217-225.

Thrower JS (2003). Natural and Managed Stand Yield Tables for the Merritt IFPA Innovative Analysis Project: MTI-402, Prepared for NicolaSimilkameen Innovative Forestry Society Merritt, British Columbia, Canada.

Waring RH, Running SW (1998). Forest ecosystems, analysis at multiple scales. Academic Press, New York, USA.

Wyszomirski T, Wyszomirska I, Jarzyna I (1999). Simple mechanism of size distribution dynamics in crowded and uncrowded virtual monocultures. Ecological Modelling 115: 253-273.

Zeide B (1993). Analysis of growth equations. Forest Science 39: 591-616. 